\title{
NORTHERNMOST RECORDS OF GADELLA MARALDI (ACTINOPTERYGII: GADIFORMES: MORIDAE) IN THE NORTH-EASTERN ATLANTIC
}

\author{
Susana RUIZ-PICO ${ }^{1 *}$, Juan C. ARRONTE ${ }^{1}$, Rafael BAÑÓN ${ }^{2}$, \\ and Olaya FERNÁNDEZ-ZAPICO ${ }^{1}$ \\ ${ }^{1}$ Instituto Español de Oceanografia, Centro Oceanográfico de Santander, Spain \\ ${ }^{2}$ Servizo de Planificación, Dirección Xeral de Recursos Mariños, Consellería de Pesca e Asuntos Marítimos, \\ Santiago de Compostela, Spain
}

Ruiz-Pico S., Arronte J.C., Bañón R., Fernández- Zapico O. 2012. Northernmost records of Gadella maraldi (Actinopterygii: Gadiformes: Moridae) in the north-eastern Atlantic. Acta Ichthyol. Piscat. 42 (3): $263-267$.

\begin{abstract}
Four specimens of Gadella maraldi (Moridae) were captured in the north-eastern Atlantic. One specimen was caught off the Galician coast (north-western Spain) and three individuals on the Porcupine Bank (off western Ireland). Morphometric measurements and meristic counts of one specimen were recorded. The Irish specimens constitute a new northern limit for the distribution of this species in the north-eastern Atlantic.
\end{abstract}

Keywords: Gadella maraldi, new records, Porcupine Bank, seamount, northern limit

The family Moridae, also known as morid cods, includes 110 species and 18 genera (Okamoto et al. 2007). The genus Gadella Lowe, 1843 comprises 13 species distributed from temperate- to tropical regions in the deep sea (usually deeper than $150 \mathrm{~m}$ ) of almost all oceans (Okamoto et al. 2010). Gadella specimens can be distinguished from the other morid genera by the presence of a ventral light organ in advance of the anus and by the absence of a barbel (Paulin 1989, Trunov 1992). However, Sazonov and Shcherbachev (2000) questioned the absence of a barbel as a distinguishing character and they pointed out that comparative anatomical investigations are needed to determine the real rank and taxonomical position of Gadella.

In the Eastern Atlantic, only three species of Gadella have been reported: Gadella imberbis (Vaillant, 1888), known from Cape Verde to Namibia (Froese and Pauly 2012), Gadella svetovidovi Trunov, 1992, known only from scattered localities from Western Sahara and the Canary Islands (Sazonov 1996, Brito et al. 2002), and Gadella maraldi (Risso, 1810), reported off southern Portugal, Madeira, Josephine Bank, Azores, Great Meteor Bank, Canary Islands, off north-western Spain and the Mediterranean Sea (Maul 1952, Shcherbachev et al. 1985, Saldanha et al. 1995, Santos et al. 1997, Uiblein et al. 1999, Brito et al. 2002, Bañón et al. 2010).

Four specimens of $G$. maraldi were caught during surveys carried out in autumn by the Instituto Español de Oceanografía (IEO) (Table 1, Fig. 1). Three individuals were captured by bottom trawl on the Porcupine Bank using a Baca-GAV 39/52 with a cod-end mesh size of 20 $\mathrm{mm}$ during the annual surveys carried out since 2001 in

Table 1

Records of Gadella maraldi off the north-western coast of Spain and on the Porcupine Bank

\begin{tabular}{lccccc}
\hline Area & Date & Latitude & Longitude & Depth (m) & TL (mm) \\
\hline Northern Spain & 2 Oct 1996 & $43^{\circ} 53^{\prime} 37 \mathrm{~N}$ & $8^{\circ} 40^{\prime} 57 \mathrm{~W}$ & 437 & 78 \\
Northern Spain & 7 Oct 2009 & $43^{\circ} 40^{\prime} 50 \mathrm{~N}$ & $8^{\circ} 52^{\prime} 08 \mathrm{~W}$ & 567 & $115^{\mathrm{B}}$ \\
Porcupine Bank & 7 Sep 2003 & $51^{\circ} 13^{\prime} 27 \mathrm{~N}$ & $13^{\circ} 52^{\prime} 49 \mathrm{~W}$ & 556 & 155 \\
Porcupine Bank & 25 Sep 2011 & $53^{\circ} 57^{\prime} 38 \mathrm{~N}$ & $12^{\circ} 55^{\prime} 26 \mathrm{~W}$ & 591 & 157 \\
Porcupine Bank & 1 Oct 2011 & $53^{\circ} 15^{\prime} 56 \mathrm{~N}$ & $14^{\circ} 34^{\prime} 15 \mathrm{~W}$ & 490 & 171 \\
\hline
\end{tabular}

B Specimen recorded in Bañón et al. (2010).

\footnotetext{
* Correspondence: Dr Susana Ruiz-Pico, Instituto Español de Oceanografía, Centro Oceanográfico de Santander, Promontorio de San Martín s/n, 39004, Santander,
} Spain, phone: +34 942291716, fax: +34 942275072, e-mail: susana.ruiz@st.ieo.es. 
ICES Subdivisions VIIb and VIIk. One specimen was caught with a Baca trawl 44/60 with a cod-end mesh size of $10 \mathrm{~mm}$ during the annual bottom trawl survey undertaken since 1983 on the northern continental shelf of Spain (ICES Subdivisions VIIIc and IXa).

Only the specimen caught on 25 September 2011 from the Porcupine Bank (Fig. 2) could be fixed in 10\% formalin, preserved in $70 \%$ alcohol and stored in the fish collection of the IEO in Santander (IEOST11001). Measurements were taken on the preserved specimen following Hubbs and Lagler (1958).

The specimen showed the main distinctive characters of the species: body elongate, compressed, and tapering posteriorly; head long with snout rather broad and obtusely rounded; chin barbel absent; no teeth on vomer and palatines; pectoral fin extending far past anal fin origin; body and head covered with small cycloid scales with exception of lips and chin; light organ present as small, scaleless patch on belly. Fresh coloration dark brown; oper- culum covered by numerous small dark spots; belly and sides below pectoral fins bluish-black; oral cavity pale.

According to Paulin (1989) and Trunov (1992), $G$. maraldi can be distinguished from the other two species of Gadella present in the eastern Atlantic by the length of the ventral fins, reaching the base of the 7th anal fin ray, while in G. svetovidovi they only reach the anterior edge of the anal fin base and in G. imberbis to the base of the 4th anal fin ray. Moreover, these authors pointed out that these species could also be separated by the upper jaw dentition. Thus, G. maraldi has two rows of teeth with the outermost row consisting of sharp, fang-like teeth, separated from each other by smaller teeth. G. svetovidovi has two rows of large canine-like teeth while $G$. imberbis has two rows of smaller, more closely set teeth.

Nearly all the morphometric- (Table 2) and meristic data (Table 3) are in agreement with the body proportions and radial formulae reported by other authors in the north-

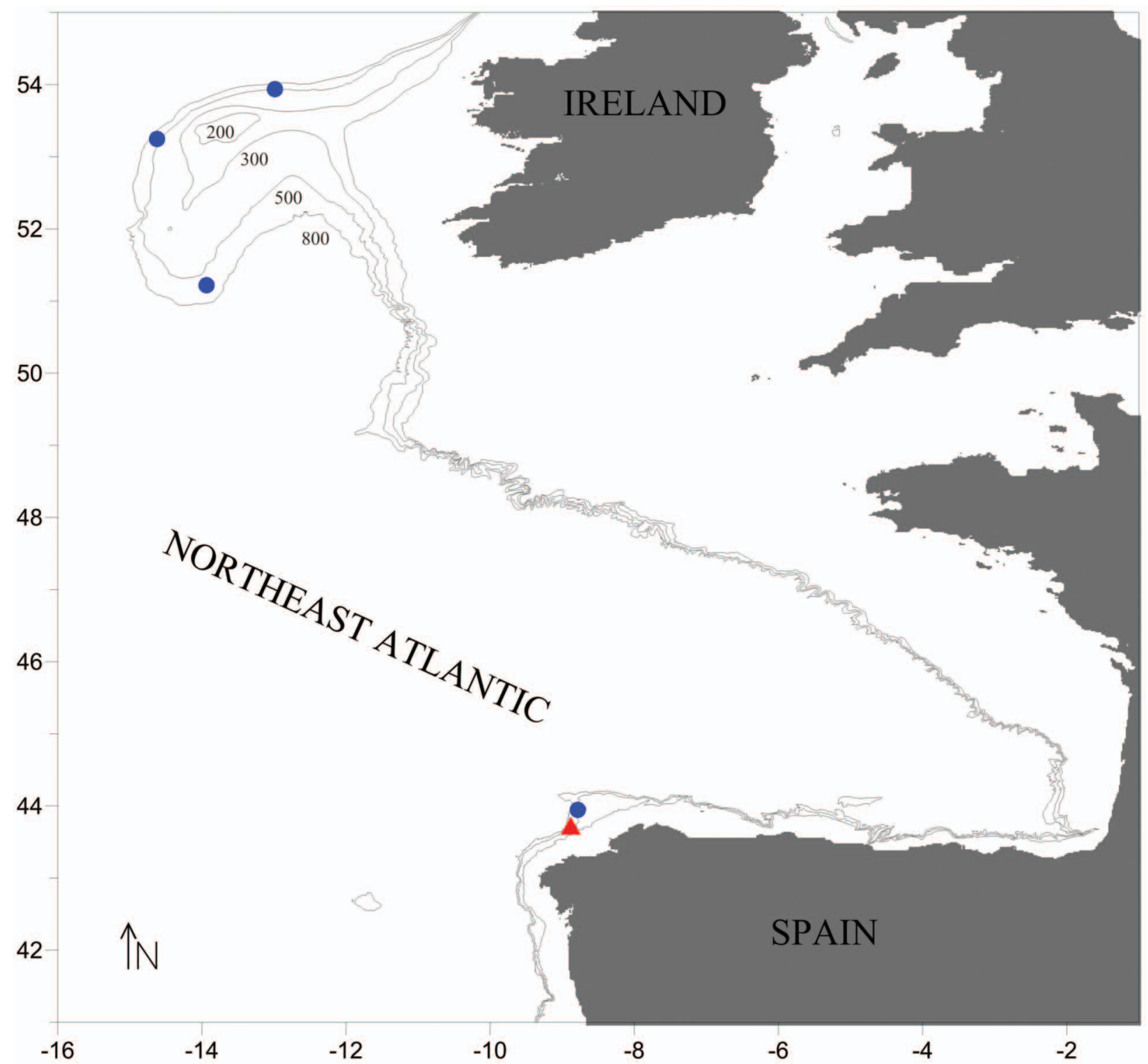

Fig. 1. Geographic distribution of the captures of Gadella maraldi; Blue circles represent the new records and the red triangle shows the specimen recorded in Bañón et al. (2010) 
eastern Atlantic and the Mediterranean Sea (Maul 1952, and latitude of the specimens. The geographical variations Aguiar and Pereira 1982, Kabasakal 1998). The only may be associated with changes in environmental condiexceptions were the slight deviations observed in head tions, mainly temperature, which is known to be an imporlength, inter-orbital distance and pre-first dorsal length. tant cause of morphometric variations (Barlow 1961). Although the number of measured specimens of G. maral- Likewise, all specimens were captured within the known $d i$ is very low, these variations could lie within the natural range of length and depth reported for this species, up to range of this species or could also be due to the different $300 \mathrm{~mm}$ TL and 150-748 m depth (Cohen et al. 1986, geographic origin (Mediterranean Sea and Atlantic Ocean) Froese and Pauly 2012) (Table 1).

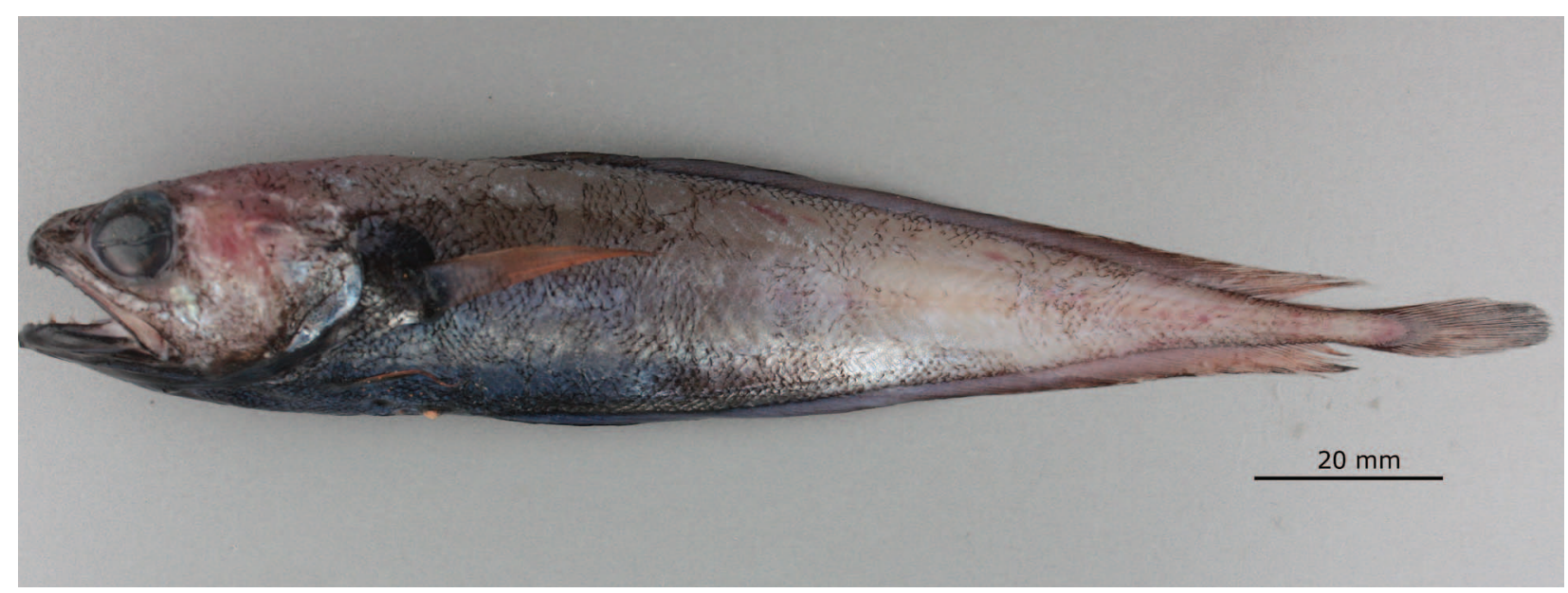

Fig. 2. Gadella maraldi (157 mm TL) caught on the Porcupine Bank in 2011 (Specimen No. IEOST11001)

Table 2

Morphometric data and weight of Gadella maraldi according to different sources

\begin{tabular}{|c|c|c|c|c|c|c|c|c|c|}
\hline \multirow{2}{*}{ Parameter } & \multicolumn{3}{|c|}{ Presently reported study } & \multicolumn{2}{|c|}{ Aguiar and Pereira (1982) } & \multicolumn{4}{|c|}{ Kabasakal (1998) } \\
\hline & {$[\mathrm{mm}]$} & {$[\% \mathrm{SL}]$} & [g] & {$[\mathrm{mm}]$} & {$[\% \mathrm{SL}]$} & {$[\mathrm{mm}]$} & {$[\% \mathrm{SL}]$} & {$[\mathrm{mm}]$} & {$[\% \mathrm{SL}]$} \\
\hline Total length (TL) & 157 & & & 278 & & 206 & & 176 & \\
\hline Standard length (SL) & 141 & & & 245 & & 181 & & 158 & \\
\hline Head length & 35 & 24.8 & & & 26.3 & & 28.2 & & 25.9 \\
\hline Snout length & 9 & 6.8 & & & 7.1 & & 7.2 & & 7.6 \\
\hline Post-orbital length & 18 & 12.8 & & & 11.4 & & 13.3 & & 12.7 \\
\hline Inter-orbital distance & 9 & 6.4 & & & 7.1 & & 8.8 & & 8.2 \\
\hline Eye diameter & 9 & 6.4 & & & 6.3 & & 7.7 & & 6.3 \\
\hline Maxillar length & 17 & 12.1 & & & - & & - & & - \\
\hline Pre-1st dorsal length & 46 & 32.6 & & & 29.8 & & - & & - \\
\hline Pre-2nd dorsal length & 54 & 38.3 & & & - & & - & & - \\
\hline Pre-anal length & 48 & 34.0 & & & 34.5 & & - & & - \\
\hline 1st dorsal fin base & 12 & 8.5 & & & - & & 8.8 & & 8.9 \\
\hline 2nd dorsal fin base & 78 & 55.3 & & & - & & 55.8 & & 55.7 \\
\hline Anal fin base & 89 & 63.1 & & & - & & 65.2 & & 64.6 \\
\hline Pectoral fin length & 28 & 19.9 & & & 19.2 & & 18.2 & & 19.6 \\
\hline Ventral fin length & 22 & 15.6 & & & - & & - & & - \\
\hline Body maximum depth & 32 & 22.7 & & & 22.0 & & 24.3 & & 24.1 \\
\hline Body maximum width & 16 & 11.3 & & & - & & - & & - \\
\hline Weight & & & 19.7 & & & & & & \\
\hline
\end{tabular}

Presently reported study was based on a single specimen deposited in the fish collection of the Instituto Español de Oceanografía in Santander, Spain (Specimen No. IEOST11001). 
Meristic data of Gadella maraldi according to different sources

\begin{tabular}{|c|c|c|c|c|c|}
\hline Parameter & $\begin{array}{c}\text { Presently } \\
\text { reported study }\end{array}$ & Maul (1952) & $\begin{array}{c}\text { Aguiar and } \\
\text { Pereira (1982) }\end{array}$ & \multicolumn{2}{|c|}{ Kabasakal (1998) } \\
\hline 1st dorsal fin rays & 10 & $11-12$ & 11 & 11 & 10 \\
\hline 2nd dorsal fin rays & 54 & 60 & 55 & 54 & 54 \\
\hline Anal fin rays & 60 & $66-67$ & 61 & 57 & 57 \\
\hline Pectoral fin rays & 24 & 25 & 24 & 24 & 20 \\
\hline Ventral fin rays & 7 & 7 & 7 & 7 & 7 \\
\hline Branchiostegal rays & 6 & 7 & 7 & - & 一 \\
\hline Total gill rakers & 12 & - & - & 11 & 11 \\
\hline Pyloric caeca & 11 & 11 & 11 & - & - \\
\hline
\end{tabular}

Presently reported study was based on a single specimen deposited in the fish collection of the Instituto Español de Oceanografía in Santander, Spain (Specimen No. IEOST11001).

Although the occurrence of this species in the western part of the Iberian Peninsula was previously indicated by Cohen et al. (1986), no data of its presence in this area was provided until one specimen was captured off southern Portugal (Saldanha et al. 1995) and subsequently in the north-western Spain (Bañón et al. 2010). Thus, the presently studied specimens represents the third record of G. maraldi caught in this area in the last 20 years.

The presently studied specimens from the Porcupine Bank constitute a significant extension $(\sim 1200 \mathrm{~km})$ from the previously known northern distributional limit of $G$. marald $i$ in the North-eastern Atlantic (off the north-west coast of Spain). They may also represent another example of the presence of this species on isolated seamounts and off islands in the north-eastern Atlantic such as Madeira, Josephine Bank, Azores, Great Meteor Bank, and Canary Islands. The Porcupine Bank exhibits similar features to a seamount with an anticyclonic eddy and associated upwelling on the bank summit and contrasting depths. The north-western part of the bank descends abruptly down to depths greater than $4000 \mathrm{~m}$, while the south-eastern part has a gentle slope and the eastern part is connected to the Irish shelf by the narrow Slyne Ridge (330-340 $\mathrm{m}$ depth). The shallowest depth is $150 \mathrm{~m}$ at the top of the bank (Mohn et al. 2002, White 2007).

The presence of tropical and subtropical species northward of their known distribution range has been proposed as a possible effect of climatic change (Quéro et al. 1998, Poulard and Blanchard 2005). Moreover, a shelf edge current of relatively saltier and warmer water has been reported around the Porcupine Bank (Pingree and Le Cann 1990, Mohn and White 2007). Both factors could encourage the displacement and the presence of warmwater fish species in the area. However, there is currently insufficient data to support either of these two hypotheses.

\section{ACKNOWLEDGEMENTS}

The authors wish to thank all participants in the Porcupine 11 research cruise and the crew of the $R V V I Z$ CONDE DE EZA for their help during sampling. We would like to express our thanks to Declan Quigley (SeaFisheries Protection Authority, Howth, Co Dublin, Ireland), Francisco Velasco (Instituto Español de Oceanografía, Spain), and Francisco Baldó (Instituto Español de Oceanografía, Spain) for their valuable comments on the manuscript.

\section{REFERENCES}

Aguiar A., Pereira J.A. 1982. Physiculus dalwigki Kaup, 1858 and Gadella maraldi (Risso, 1810) newly recorded in Azorean waters (Pisces: Moridae). Cybium 6 (3): 35-38.

Bañón R., Villegas-Ríos D., Serrano A., Mucientes G., Arronte J.C. 2010. Marine fishes from Galicia (NW Spain): an updated checklist. Zootaxa 2010 (2667): 1-27.

Barlow G.W. 1961. Causes and significance of morphological variation in fishes. Systematic Zoology 10 (3): 105-117.

Brito A., Pascual P.J., Falcón J.M., Sancho A., González G. 2002. Peces de las Islas Canarias. Catálogo comentado e ilustrado. Francisco Lemus Editor, La Laguna, Islas Canarias, Spain.

Cohen D.M. 1986. Moridae. Pp. 713-723. In: Whitehead P.J.P., Bauchot M.-L., Hureau J.C., Nielsen J., Tortonese E. (eds.) Fishes of the north-eastern Atlantic and the Mediterranean. UNESCO, Paris.

Froese R., Pauly D. (eds.) 2012. FishBase. [version 08/2012] http://www.fishbase.org

Hubbs C.L., Lagler K.F. 1958. Fishes of the Great Lakes region. Bulletin of Cranbrook Institute of Science 26: 1-213.

Kabasakal H. 1998. Confirmation of the presence of Gadella maraldi (Risso, 1810) in the seas of Turkey. Institut za oceanografiju i ribarstvo, Split, Croatia 80: 1-8.

Maul G.E. 1952. Monografia dos peixes do Museu Municipal do Funchal. Familia Gadidae e Bregmacerotidae. [Monograph of the fishes of the Funchal Museum. Family Gadidae and Bregmacerotidae]. Boletim do Museu Municipal do Funchal 6 (15): 5-51. [In Portugease.]

Mohn C., Bartsch J., Meincke J. 2002. Observations of the mass and flow field at Porcupine Bank. ICES Journal of Marine Science 59 (2): 380-392.

DOI: $10.1006 /$ jmsc.2001.1174 
Mohn C., White M. 2007. Remote sensing and modelling of bio-physical distribution patterns at Porcupine and Rockall Bank, northeast Atlantic. Continental Shelf Research 27 (14): $1875-1892$.

DOI: $10.1016 / j . c s r .2007 .03 .006$

Okamoto M., Matsuda K., Matsuda T. 2010. Description of a pelagic juvenile specimen of Gadella jordani (Actinopterygii: Gadiformes: Moridae) from southern Japan, with a note on the color in life. Species Diversity 15: 131-138.

Okamoto M., Sato N., Asahida T., Watanabe Y. 2007. Pelagic juveniles of two morids (Teleostei: Gadiformes: Moridae), Antimora microlepis and Physiculus japonicus, from the western North Pacific. Species Diversity 12 (1): $17-27$.

Paulin C.D. 1989. Review of the morid genera Gadella, Physiculus, and Salilota (Teleostei: Gadiformes) with descriptions of seven new species. New Zealand Journal of Zoology 16 (1): 93-133.

DOI: $10.1080 / 03014223.1989 .10423706$

Pingree R., Le Cann B. 1990. Celtic and Armorican slope and shelf residual currents. Progress in Oceanography 23 (4): 303-338. DOI: 10.1016/0079-6611(89)90003-7

Poulard J.C., Blanchard F. 2005. The impact of climate change on the fish community structure of the eastern continental shelf of the Bay of Biscay. ICES Journal of Marine Science 62 (7): 1436-1443.

DOI: $10.1016 /$ j.icesjms.2005.04.017

Quéro J.-C. 1998. Changes in the Euro-Atlantic fish species composition resulting from fishing and ocean warming. Italian Journal of Zoology 65 (Suppl. 1): 493-499. DOI: 10.1080/11250009809386873

Saldanha L., Almeida A.J., Andrade F., Guerreiro J. 1995. Observations on the diet of some slope dwelling fishes of southern Portugal. Internationale Revue der gesamten Hydrobiologie und Hydrographie 80 (2): 217-234. DOI: 10.1002/iroh.19950800210
Santos R.S., Porteiro F.M., Barreiros J.P. 1997. Marine fishes of the Azores. Annotated checklist and bibliography. A catalogue of the Azorean marine ichthyodiversity. Arquipélago-Life and Marine Sciences, Bulletin of the University of Azores 1997 (Suppl. 1): 1-244.

Sazonov Y.I. 1996. A new record of the rare species Gadella svetovidovi (Gadiformes, Moridae) off the northwest Africa coast. Journal of Ichthyology 36 (6): 473-475.

Sazonov Y.I., Shcherbachev Y.N. 2000. A Review of the Indian Ocean species from the genus Gadella (Gadiformes, Moridae), with a description of two new species. Journal of Ichthyology 40 (Suppl. 1): S64-S73.

Shcherbachev Y.N., Kukuev E.I., Shlibanov V.I. 1985. Composition of the benthic and demersal ichthyocenoses of the submarine mountains in the southern part of the North Atlantic Range. Journal of Ichthyology 25 (?): 110-125.

Trunov I.A. 1992. Fish of the family Moridae from the southeastern Atlantic (Genera Gadella, Halargyreus, and Antimora). Journal of Ichthyology 32 (4): 38-45.

Uiblein F., Geldmacher A., Köster F., Nellen W., Kraus G. 1999. Species composition and depth distribution of fish species collected in the area of the Great Meteor Seamount, eastern central Atlantic, during cruise M42/3, with seventeen new records. Informes técnicos del Instituto Canario de Ciencias Marinas 5: 47-85.

White M. 2007. Benthic dynamics at the carbonate mound regions of the Porcupine Sea Bight continental margin. International Journal of Earth Sciences 96 (1): 1-9. DOI: $10.1007 / \mathrm{s} 00531-006-0099-1$

Received: 10 May 2012

Accepted: 21 August 2012 Published electronically: 30 September 2012 